\title{
Reduction of Excretory Phosphorus and Trace Minerals by Dietary Supplementation of Microbial Phytase in Broiler Chicks
}

\author{
Chisato Yonemochi ${ }^{1)}$, Hisao Takagi ${ }^{1)}$, Toru Okada ${ }^{2)}$, Takahumi Ina ${ }^{2)}$ \\ and Kazuyuki Koide ${ }^{2)}$ \\ 1) Japan Scientific Feeds Association, Chiyoda-Ku, Tokyo 101-0062, Japan \\ ${ }^{2)}$ Kyowa Hakko Kogyo Co., Ltd., Chiyoda-Ku, Tokyo 100-8185, Japan
}

\begin{abstract}
An experiment was conducted to study the effect of microbial phytase on excretory phosphorus $(\mathrm{P})$, copper $(\mathrm{Cu})$, zinc $(\mathrm{Zn})$ and manganese $(\mathrm{Mn})$ in broiler chicks. Male broiler chicks with three replications of 10 chicks each were given free access to the experimental diet from 7 to 21 days of age. The basal diet consisted mainly of corn, soybean meal and defatted rice bran, and contained $0.60 \%$ total $\mathrm{P}, 0.30 \%$ non-phytate $\mathrm{P}$, $0.90 \%$ calcium, $8.1 \mathrm{mg} \mathrm{Cu}, 82.3 \mathrm{mg} \mathrm{Zn}$ and $95.3 \mathrm{mg} \mathrm{Mn}$ per $\mathrm{kg}$ of diet, and $0.1 \%$ chromium oxide as an indicator. To the basal diet, defluorinated phosphate (0.075 and $0.15 \%$ as non-phytate $\mathbf{P})$ or microbial phytase $(125,250$ and 500 units $/ \mathrm{kg}$ of diet) was added. The excreta of each replication were collected for the last three days of the experiment, and the retention ratio and excretion of total $\mathrm{P}$, phytate $\mathrm{P}, \mathrm{Cu}, \mathrm{Zn}$ and $\mathrm{Mn}$ were calculated.

The retention ratio of total $\mathrm{P}, \mathrm{Cu}$ and $\mathrm{Zn}$ increased almost linearly with the increase of supplemented phytase. When 500 units $/ \mathrm{kg}$ phytase were added, total $\mathrm{P}$ excretion was reduced by $31 \%$, and the excretion of $\mathrm{Cu}$ and $\mathrm{Zn}$ was also reduced by $7 \%$, respectively, in comparison with the diet containing $0.45 \%$ non-phytate P. However, the excretion of $\mathrm{Mn}$ was not affected by the addition of phytase.
\end{abstract}

Key words : broiler, mineral excretion, microbial phytase, phytate phosphorus, trace minerals

\section{Introduction}

More than $50 \%$ of phosphorus (P) contained in plant feedstuffs occur as phytate $\mathrm{P}$. It has been well known that phytate $\mathrm{P}$ is poorly used by poultry (Japanese Feeding Standard for Poultry, JFSP, 1997). Phytic acid is a strong acid and forms various chelate compounds with important trace minerals such as zinc $(\mathrm{Zn})$, copper $(\mathrm{Cu})$, magnesium $(\mathrm{Mg})$, manganese $(\mathrm{Mn})$, iron $(\mathrm{Fe})$ and potassium $(\mathrm{K})$. These chelate compounds are poorly used by non-ruminant animals such as poultry and swine, because it has low solubility (Oberleas, 1973).

Nelson et al. (1971) first demonstrated that the availability of phytate $\mathrm{P}$ was improved by the addition of microbial phytase to the chick diets. After that, many investigators have reported that the availability of phytate $\mathbf{P}$, growth performance and 
accumulation of bone ash are improved by the addition of phytase (Schörner et al., 1993 ; Broz et al., 1993 ; Perney et al., 1993 ; Roberson et al., 1994 ; Takemasa et al., 1995 ; Mitchell et al., 1996 ; Sevastian et al., 1996 ; and Yi et al., 1996a). In the previous report (Yonemochi et al., 2000), it was confirmed that not only growth performance, tibia ash and plasma inorganic $\mathrm{P}$, but also apparent $\mathrm{ME}$ and nitrogen retention of broiler chicks were significantly improved by the addition of phytase to the chick diet.

It was also reported that phytase improved the availability of calcium (Ca), $\mathrm{Zn}$ and $\mathrm{Cu}$ (Sevastian et al., 1996 ; and Yi et al., 1996b ; and Aoyagi and Baker, 1995). When phytic acid is hydrolyzed by phytase, it is expected that the released phytatebound minerals are available more effectively for animals and the excretion of these minerals is reduced. However, there is little information about the excretory and retention of phytate $\mathrm{P}$ and trace minerals in broiler chicks fed the diets supplemented by microbial phytase. Therefore, in this study, effects of dietary phytase on reduction of excretory total $\mathrm{P}$, phytate $\mathrm{P}, \mathrm{Zn}, \mathrm{Cu}$ and $\mathrm{Mn}$ were investigated in broiler chicks.

\section{Materials and methods}

\section{Design of Experiment}

One hundred and eighty male Arbor Acres chicks of 7 days of age were assigned to six dietary treatments. Each treatment consisted of 3 replications of 10 chicks each and chicks were given free access to the experimental diets and water for 14 days.

The excreta of each replication were collected twice a day for the last three days of the experimental period.

2. Diet

The composition of the basal diet (Diet 1) is shown in Table 1. The basal diet consisted mainly of corn, soybean meal and defatted rice bran, and contained $21.4 \%$ $\mathrm{CP}, 3.11 \mathrm{Mcal} \mathrm{ME} / \mathrm{kg}$ of diet, $0.60 \%$ total $\mathrm{P}, 0.30 \%$ non-phytate $\mathrm{P}, 0.90 \% \mathrm{Ca}, 8.1 \mathrm{mg}$ $\mathrm{Cu}, 82.3 \mathrm{mg} \mathrm{Zn}$ and $95.3 \mathrm{mg} \mathrm{Mn}$ per $\mathrm{kg}$ of diet, and $0.1 \%$ chromium oxide as an indigestible marker. The basal diet met recommended (JSFP, 1997) nutrient requirements expect for that of non-phytate $P$.

Diets 2 and 3 were prepared by adding 0.075 and $0.15 \%$ non-phytate $\mathrm{P}$ in the form of defluorinated phosphate to the basal diet, respectively. Diets 4,5 and 6 were supplemented by 125, 250 and 500 units microbial phytase per $\mathrm{kg}$ of the basal diet, respectively.

Microbial phytase was obtained by fermentation of non-recombinant Aspergillus

niger in the laboratory of Kyowa Hakko Kogyo Co., Ltd. (Tokyo, Japan). The microbial phytase preparation contained 500 units/g phytase. One unit of phytase activity is defined as the amount of enzyme which liberates $1 \mu \mathrm{mol}$ inorganic $\mathrm{P}$ per min from 0.0051 mol sodium phytate at $37^{\circ} \mathrm{C}$ and $\mathrm{pH} 5.5$.

3. Analysis

The excreta collected for three days were mixed, dried at $60^{\circ} \mathrm{C}$ in a ventilated oven, and ground through $1 \mathrm{~mm}$ sieve.

Total $\mathbf{P}$ and phytate $\mathbf{P}$ in excreta and diets were determined by the 
Table 1. Composition of the basal diet

\begin{tabular}{|c|c|}
\hline Ingredients & $(\%)$ \\
\hline Corn & 56.91 \\
\hline Soybean meal $(46 \% \mathrm{CP})$ & 22.50 \\
\hline Defatted rice bran & 8.00 \\
\hline Soybean oil & 4.00 \\
\hline Casein & 5.00 \\
\hline Calcium carbonate & 2.20 \\
\hline Defluorinated phosphate & 0.36 \\
\hline Sodium chloride & 0.40 \\
\hline DL-methionine & 0.22 \\
\hline L-lysine- $\mathrm{HCl}$ & 0.01 \\
\hline Vitamin premix ${ }^{1}$ & 0.20 \\
\hline Mineral premix ${ }^{2}$ & 0.10 \\
\hline Chromium oxide & 0.10 \\
\hline \multicolumn{2}{|l|}{ Chemical Analysis } \\
\hline $\mathrm{ME}(\mathrm{Mcal} / \mathrm{kg})^{3}$ & 3.11 \\
\hline $\mathrm{CP}(\%)$ & 21.40 \\
\hline Total P (\%) & 0.60 \\
\hline Non-phytate P $(\%)$ & 0.30 \\
\hline $\mathrm{Ca}(\%)$ & 0.90 \\
\hline $\mathrm{Zn}(\mathrm{mg} / \mathrm{kg})$ & 82.3 \\
\hline $\mathrm{Cu}(\mathrm{mg} / \mathrm{kg})$ & 8.1 \\
\hline $\mathrm{Mn}(\mathrm{mg} / \mathrm{kg})$ & 95.3 \\
\hline
\end{tabular}

${ }^{1}$ Contains (IU or $\mathrm{g} / \mathrm{kg}$ premix) $:\left(10^{6} \mathrm{IU}\right)$ vit. A, 5.0 ; vit. $\mathrm{D}_{3}, 1.0 ;(\mathrm{g})$ vit. E, 0.01 ; vit. $\mathrm{K}_{3}, 1$; thiamin, 1 ; riboflavin, 4 ; pantothetic acid, 15 ; nicotinic acid, 30 ; pyridoxine, 2 ; biotin, 0.1 ; folic acid, 0.5 ; choline, 0.25 ; cyanocobalamin, 0.005 and defatted rice bran to $1 \mathrm{~kg}$.

${ }^{2}$ Contains (g/kg premix) : Mn, $80 ; \mathrm{Zn}, 50 ; \mathrm{Fe}, 6 ; \mathrm{Cu}, 0.6 ; \mathrm{I}, 1$ and defatted rice bran to $1 \mathrm{~kg}$.

${ }^{3}$ Based on JSFP (1997).

phosphomolybdix acid method (Fiske and Subbarow, 1925). $\mathrm{Zn}, \mathrm{Cu}$ and $\mathrm{Mn}$ in excreta and diets were determined with a flame atomic absorption spectrophotometer (AOAC, 1990). Chromium oxide in excreta and diets was determined by the colorimetric procedure (AOAC, 1990). The retention ratios of total $\mathrm{P}$, phytate $\mathrm{P}, \mathrm{Zn}, \mathrm{Cu}$ and $\mathrm{Mn}$ were calculated by the indicator method.

\section{Statistical Analysis}

The data were analyzed using the General Linear Models procedure for analysis of variance (SAS Institute, 1990). Significant differences among treatment groups were determined by Tukey's multiple range test (Yoshida, 1983). The nonlinear equations $\left[\mathrm{Y}=\mathrm{a}\left(1-\mathrm{be}^{-\mathrm{kX}}\right)\right]$ were derived for non-phytate P levels (Diets 1, 2 and 3 ) and phytase levels (Diets 1, 4, 5 and 6) using the Non-linear Regression procedure of SAS (1990) : 
where $\mathrm{Y}=$ the retention of total $\mathrm{P}$ or phytate $\mathrm{P}$ ( $\mathrm{g} / 14$ days) $\mathrm{X}=$ percentage of added non-phytate $\mathbf{P}$ (percentage) or phytase (units/kg diet), respectively.

\section{Result and Discussion}

As shown in Table 2, with increasing dietary non-phytate $\mathbf{P}$ added as defluorinated phosphate to Diets 1 to 3 , the retention ratio of total $\mathbf{P}$ increased significantly and reached a maximum value at $0.45 \%$ non-phytate $P$. However, the retention ratio of phytate $\mathbf{P}$ was not affected by increasing dietary non-phytate $\mathbf{P}$.

Furthermore, with increasing dietary non-phytate $\mathbf{P}$, total $\mathbf{P}$ excretion increased significantly. This is because the feed intake and the total $\mathbf{P}$ intake increased with the non-phytate $\mathrm{P}$ addition and $\mathrm{P}$ from defluorinated phosphate might not be used completely. De Groote and Huyghebaert (1977) reported that the retention ratio of $\mathbf{P}$ from the monobasic calcium phosphate in broiler chicks ranged from $78.1 \%$ to $85.5 \%$. Furthermore, the bioavailability of $\mathbf{P}$ from defluorinated phosphate is lower than that from monobasic calcium phosphate in the broiler chicks (Coffey et al., 1994). These results show that $\mathrm{P}$ excretion increases when defluorinated phosphate are added to satisfy non-phytate $P$ requirement of chicks.

On the other hand, in Diets 4, 5 and 6, the retention of total $P$ and phytate $P$ increased as dietary phytase levels were increased (Table 2).

With increasing dietary non-phytate $\mathbf{P}$ or added phytase, the total $\mathbf{P}$ retention increased nonlinearly as follows :

Table 2. Effect of dietary non-phytate phosphorus (P) and phytase levels on intake, excretion and retention of total and phytate $\mathrm{P}$ in male broiler chicks during 7 to 21 days of age

\begin{tabular}{lccccccc}
\hline \hline Diet No. & 1 & 2 & 3 & 4 & 5 & 6 & \\
Basal non-phytate P (\%) & 0.30 & 0.30 & 0.30 & 0.30 & 0.30 & 0.30 & Pooled \\
Added non-phytate P (\%) & 0 & 0.075 & 0.15 & 0 & 0 & 0 & SE \\
Added phytase (unit/kg) & 0 & 0 & 0 & 125 & 250 & 500 & \\
\hline Body weight gain (g/14 days) & $342^{\mathrm{d}}$ & $423^{\mathrm{bc}}$ & $457^{\mathrm{a}}$ & $392^{\mathrm{c}}$ & $418^{\mathrm{c}}$ & $451^{\mathrm{ab}}$ & 3 \\
Feed intake (g/14 days) & $588^{\mathrm{d}}$ & $684^{\mathrm{abc}}$ & $728^{\mathrm{a}}$ & $646^{\mathrm{c}}$ & $673^{\mathrm{bc}}$ & $703^{\mathrm{ab}}$ & 4 \\
Intake (g/14 days) & & & & & & & \\
$\quad$ Total P & $3.53^{\mathrm{e}}$ & $4.62^{\mathrm{b}}$ & $5.46^{\mathrm{a}}$ & $3.88^{\mathrm{d}}$ & $4.04^{\mathrm{cd}}$ & $4.22^{\mathrm{c}}$ & 0.05 \\
$\quad$ Phytate P & $1.76^{\mathrm{d}}$ & $2.05^{\mathrm{bc}}$ & $2.18^{\mathrm{a}}$ & $1.95^{\mathrm{c}}$ & $2.02^{\mathrm{bc}}$ & $2.11^{\mathrm{ab}}$ & 0.02 \\
Total P excretion (g/14 days) & $2.48^{\mathrm{c}}$ & $3.10^{\mathrm{d}}$ & $3.54^{\mathrm{a}}$ & $2.57^{\mathrm{c}}$ & $2.50^{\mathrm{c}}$ & $2.43^{\mathrm{c}}$ & 0.03 \\
Retention (g/14 days) & & & & & & & \\
$\quad$ Total P & $1.05^{\mathrm{d}}$ & $1.52^{\mathrm{b}}$ & $1.92^{\mathrm{a}}$ & $1.31^{\mathrm{c}}$ & $1.54^{\mathrm{ab}}$ & $1.79^{\mathrm{a}}$ & 0.02 \\
$\quad$ Phytate P & $0.12^{\mathrm{d}}$ & $0.13^{\mathrm{d}}$ & $0.13^{\mathrm{d}}$ & $0.22^{\mathrm{c}}$ & $0.33^{\mathrm{b}}$ & $0.52^{\mathrm{a}}$ & 0.01 \\
Retention ratio (\%) & & & & & & & \\
$\quad$ Total P & $29.7^{\mathrm{e}}$ & $32.9^{\mathrm{d}}$ & $35.2^{\mathrm{c}}$ & $33.7^{\mathrm{cd}}$ & $38.1^{\mathrm{b}}$ & $42.5^{\mathrm{a}}$ & 0.30 \\
$\quad$ Phytate P & $6.5^{\mathrm{d}}$ & $6.1^{\mathrm{d}}$ & $5.7^{\mathrm{d}}$ & $11.3^{\mathrm{c}}$ & $16.4^{\mathrm{b}}$ & $24.7^{\mathrm{a}}$ & 0.50 \\
\hline
\end{tabular}

Each value is means for 3 replicates with 10 chicks.

a-d Means with different superscripts in the same row are significantly different $(\mathrm{P}$ $<0.05)$. 
$\mathrm{Y}=2.818\left(1-0.63 \mathrm{e}^{-4.11 \times 1}\right), \mathbf{R}^{2}=0.98$ for non-phytate $\mathbf{P}$ and

$\mathrm{Y}=2.138\left(1-0.51 \mathrm{e}^{-0.0023 \times 2}\right), \mathrm{R}^{2}=0.99$ for phytase. Where $\mathrm{Y}=$ the retention of total $\mathrm{P}$ (g/14 days) $; \mathrm{X} 1=$ added non-phytate $\mathrm{P}$ (percentage) $; \mathrm{X} 2=$ added phytase (units $/ \mathrm{kg}$ diet).

From these two equations, relation between added phytase and non-phytate $\mathbf{P}$ was as follows :

$2.818\left(1-0.63 \mathrm{e}^{-4.11 \times 1}\right)=2.138\left(1-0.51 \mathrm{e}^{-0.0023 \times 2}\right)$

$\mathrm{X} 1=-0.2433 \ln \left(0.3829+0.6142 \mathrm{e}^{-0.0023 \mathrm{X} 2}\right)$

For example, when $\mathrm{X} 2$ is 125 units/ $\mathrm{kg}$ of diet, the equivalent $\mathrm{X} 1$ is $0.040 \%$ [$\left.0.2433 \ln \left(0.3829+0.6142 \mathrm{e}^{-0.0023 \times 125}\right)\right]$. This result means that 125 units of phytase/ $\mathrm{kg}$ of diet is equivalent to $0.040 \%$ of non-phytate $\mathrm{P}$ for total $\mathrm{P}$ retention, which indicates that the $\mathrm{P}$ equivalency value of phytase is 312 units for $1 \mathrm{~g} \mathrm{P}$.

In the same way, the $\mathrm{P}$ equivalency values by added 250 and 500 units of phytase per $\mathrm{kg}$ of diet were calculated to be 329 and 377 units for $1 \mathrm{~g} \mathrm{P}$, respectively. These results were in agreement with the $P$ equivalency values estimated for performance and accumulation of tibia ash in the previous report (Yonemochi et al., 2000).

Furthermore, the increase of total $\mathrm{P}$ retention by added phytase almost corresponded to the increase of phytate $\mathbf{P}$ retention (Fig. 1). With increasing added phytase, the feed intake and the total $\mathbf{P}$ intake increased. However, the total $\mathbf{P}$ excretion decreased with increasing phytase level. When 500 units $/ \mathrm{kg}$ phytase was added, total $\mathrm{P}$ excretion was reduced by $31 \%$ in comparison with Diet 3 in which non-phytate $\mathbf{P}$ was adjusted to satisfy the requirements of broiler chicks. This reduced

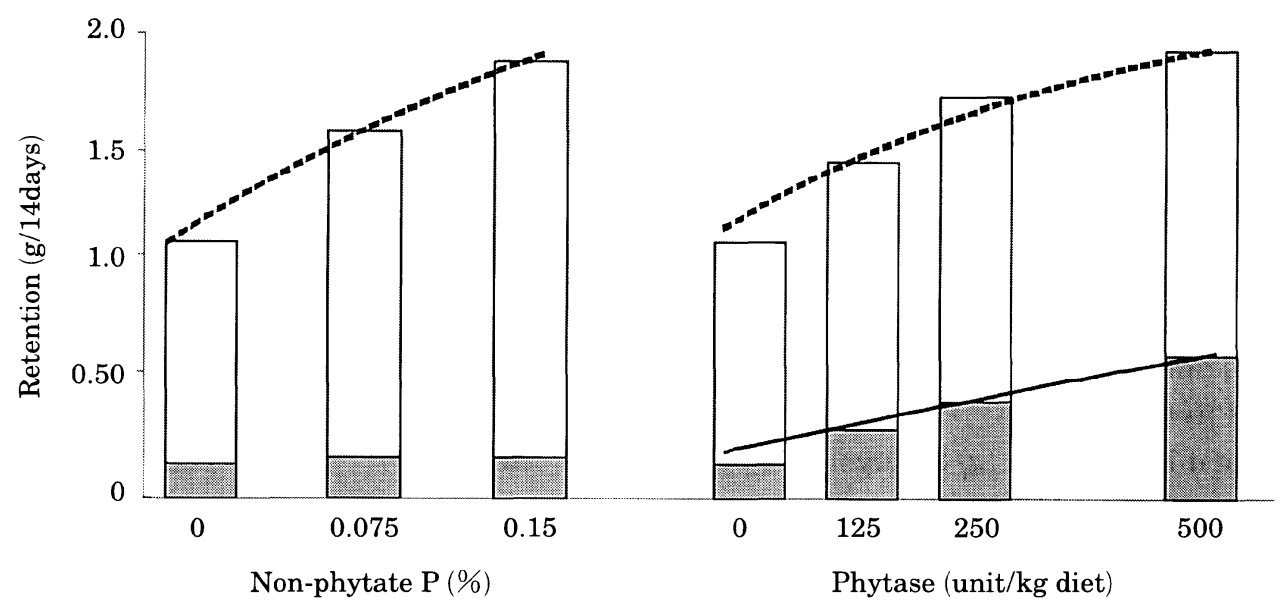

Fig. 1. Effect of dietary nonphytate phosphorus (P) and phytase levels on retention of total $\mathrm{P}$ and phytate $\mathrm{P}$ in male broiler chicks during 7 to 21 days of age ( $\square$ $+\square$ Total $\mathrm{P}, \boldsymbol{\square}$ Phytate $\mathrm{P})$

$\mathrm{A}: \mathrm{Y} 1=2.818\left(1-0.63 \mathrm{e}^{-4.11 \times 1}\right), \mathrm{B}: \mathrm{Y} 1=2.138\left(1-0.51 \mathrm{e}^{-0.023 \times 2}\right), \mathrm{C}: \mathrm{Y} 2=2.388(1-$ $\left.0.95 \mathrm{e}^{-0.0004 \times 2}\right)$; where $\mathrm{Y} 1=$ grams $/ 14$ days of total $\mathrm{P}$ retention $; \mathrm{Y} 2=$ grams $/ 14$ days of phytate $\mathrm{P}$ retention ; $\mathrm{X} 1=$ percentage of added non-phytate $\mathrm{P} ; \mathrm{X} 2=$ unit/kg of diet of added phytase. 
Table 3. Effect of dietary non-phytate phosphorus (P) and phytase levels on intake, excretion and retention of $\mathrm{Cu}, \mathrm{Zn}$ and $\mathrm{Mn}$ in male broiler chicks during 7 to 21 days of age

\begin{tabular}{lccccccc}
\hline \hline Diet No. & 1 & 2 & 3 & 4 & 5 & 6 & \\
Basal non-phytate P (\%) & 0.30 & 0.30 & 0.30 & 0.30 & 0.30 & 0.30 & Pooled \\
Added non-phytate P (\%) & 0 & 0.075 & 0.15 & 0 & 0 & 0 & SE \\
Added phytase (unit/kg) & 0 & 0 & 0 & 125 & 250 & 500 & \\
\hline Intake (mg/14days) & & & & & & & \\
Cu & $4.8^{\mathrm{d}}$ & $5.5^{\mathrm{ab}}$ & $5.9^{\mathrm{a}}$ & $5.2^{\mathrm{c}}$ & $5.5^{\mathrm{bc}}$ & $5.7^{\mathrm{ab}}$ & 0.1 \\
$\mathrm{Zn}$ & $48.4^{\mathrm{d}}$ & $56.3^{\mathrm{abc}}$ & $59.9^{\mathrm{a}}$ & $53.2^{\mathrm{c}}$ & $55.4^{\mathrm{bc}}$ & $57.9^{\mathrm{ab}}$ & 0.4 \\
$\mathrm{Mn}$ & $59.0^{\mathrm{d}}$ & $65.2^{\mathrm{bc}}$ & $69.4^{\mathrm{a}}$ & $61.6^{\mathrm{c}}$ & $64.1^{\mathrm{bc}}$ & $67.0^{\mathrm{b}}$ & 0.4 \\
Excretion (mg/ 14days) & & & & & & & \\
Cu & $4.6^{\mathrm{c}}$ & $5.4^{\mathrm{ab}}$ & $5.7^{\mathrm{a}}$ & $5.0^{\mathrm{b}}$ & $5.2^{\mathrm{ab}}$ & $5.3^{\mathrm{ab}}$ & 0.1 \\
$\mathrm{Zn}$ & $45.5^{\mathrm{c}}$ & $51.0^{\mathrm{ab}}$ & $53.5^{\mathrm{a}}$ & $48.7^{\mathrm{b}}$ & $48.4^{\mathrm{bc}}$ & $49.7^{\mathrm{ab}}$ & 0.3 \\
$\mathrm{Mn}$ & $51.8^{\mathrm{c}}$ & $61.8^{\mathrm{ab}}$ & $64.4^{\mathrm{a}}$ & $57.0^{\mathrm{bc}}$ & $60.3^{\mathrm{ab}}$ & $62.8^{\mathrm{a}}$ & 0.5 \\
Retention ratio (\%) & & & & & & & \\
Cu & $2.6^{\mathrm{e}}$ & $2.7^{\mathrm{de}}$ & $3.2^{\mathrm{cd}}$ & $4.4^{\mathrm{bc}}$ & $5.5^{\mathrm{ab}}$ & $6.5^{\mathrm{a}}$ & 0.1 \\
$\mathrm{Zn}$ & $5.9^{\mathrm{e}}$ & $9.5^{\mathrm{cd}}$ & $10.6^{\mathrm{c}}$ & $8.5^{\mathrm{d}}$ & $12.7^{\mathrm{b}}$ & $14.1^{\mathrm{a}}$ & 0.1 \\
$\mathrm{Mn}$ & 7.5 & 5.2 & 7.1 & 7.5 & 6.0 & 6.3 & 0.3 \\
\hline
\end{tabular}

Each value is means for 3 replicates with 10 chicks.

a-d means with different superscript in the same row are significantly different $(\mathrm{P}<$ $0.05)$.

Table 4. The contents of $\mathrm{Cu}, \mathrm{Zn}$ and $\mathrm{Mn}$ for mineral premix were added to those contents for the diets 1

\begin{tabular}{lccc}
\hline \hline & The content of Diet $^{1}$ & $\begin{array}{c}\text { Source for } \\
\text { mineral premix }\end{array}$ & Source for feedstuffs \\
\hline $\mathrm{Zn}(\mathrm{mg} / \mathrm{kg})$ & 82.3 & $50.0(60.8)^{2}$ & $32.2(39.2)^{3}$ \\
$\mathrm{Cu}(\mathrm{mg} / \mathrm{kg})$ & 8.1 & $0.6(7.4)$ & $7.5(92.6)$ \\
$\mathrm{Mn}(\mathrm{mg} / \mathrm{kg})$ & 95.3 & $80.0(83.9)$ & $15.3(16.1)$ \\
\hline
\end{tabular}

${ }^{1}$ See table 1.

${ }^{2}$ values in parenthesis are percentage of mineral premix to total in diets.

${ }^{3}$ values on parenthesis are percentage of feedstuffs to total in diets.

value of total $\mathbf{P}$ excretion agreed with that observed by Takemasa et al. (1995).

The retention ratio and excretion of $\mathrm{Cu}, \mathrm{Zn}$ and $\mathrm{Mn}$ are shown in Table 3. With increasing dietary non-phytate $\mathbf{P}$ or added phytase, the retention ratio of $\mathrm{Cu}$ and $\mathrm{Zn}$ increased significantly. Furthermore, the magnitude of responses for retention ratio of $\mathrm{Cu}$ and $\mathrm{Zn}$ by added phytase was larger than that of non-phytate $\mathrm{P}$. When 500 units/ $\mathrm{kg}$ phytase was added, the excretion of $\mathrm{Cu}$ and $\mathrm{Zn}$ was reduced by $7 \%$ in comparison with diet 3, respectively. This tendency was in agreement with the results of Sevastian et al. (1996) and Yi et al. (1996b). However, the retention ratio and excretion of Mn were not affected by increasing dietary levels of non-phytate $\mathbf{P}$ or phytase. 
Vohra et al. (1965) reported that phytate formed complexes with cations in the following descending order of strength : $\mathrm{Cu}>\mathrm{Zn}>\mathrm{Co}>\mathrm{Mn}>\mathrm{Fe}>\mathrm{Ca}$, the amount of liberated $\mathrm{Mn}$ by addition of phytase being lower than that of $\mathrm{Cu}$ and $\mathrm{Zn}$. In our experiment, the utilization of Mn was not improved by the addition of phytase. In addition to the finding of Vohra et al. (1965), this is due to the fact that Mn content derived from feedstuffs was far lower than $\mathrm{Cu}$ and $\mathrm{Zn}$. From analytical data, the basal diet contained organic $\mathrm{Cu}, \mathrm{Zn}$ and $\mathrm{Mn}$ derived from feedstuffs, which were 92.6, 39.2 and $16.1 \%$ of total content, respectively (Table4).

The present study demonstrated that addition of microbial phytase to the broiler diet could decrease $\mathrm{P}, \mathrm{Cu}$ and also $\mathrm{Zn}$ levels that are added to support the requirements of chicks, reducing environment pollution caused by excretory $\mathrm{P}, \mathrm{Cu}$ and $\mathrm{Zn}$ in broiler chicks.

\section{Reference}

Association of Official Analytical Chemists. Official methods of analysis, 14th Ed., Association of Official Analytical Chemists, Washington, D.C. 1990.

Aoyagi S and Baker DH. Effect of microbial phytase and 1, 25-dihydroxycholecalciferol on dietary copper utilization in chicks. Poultry Science, 74 : 121-126. 1995.

Agriculture, Forestry and Fisheries Research Council Secretariat, Ministry of Agriculture, Forestry and Fisheries. Japanese feeding standard for poultry (1997), Central Association of Livestock Industry. 1997.

Broz J, Oldele P, Perrin-voitz A-H, Rychen G, Schulze J and Simoes Nunes C. Effect of supplemental phytase on performance and phosphorus utilization in broiler chickens fed a low phosphorus diet without addition of inorganic phosphates. British Poultry Science, 35 : 273-280. 1993.

Coffey RD, Cromwell GL and Aaron DK. Biological availability of phosphorus in defluorinated phosphates with different solubilities in neutral ammonium citrate for chicks and pigs. Journal of Animal Science, $72: 2653-2660.1994$.

De Groote G and Huyghebaert G. The bio-availability of phosphorus from feed phosphates for broilers as influenced by bio-assay method, dietary Ca-level and feed form. Feed Science Technology, $69:$ 329-340. 1997.

Fiske $\mathrm{CH}$ and Subbarow Y. The colorimetric determination of phosphorus. Journal Biological Chemistry, $66: 375-400.1925$.

Mitcell RD and Edwards Jr. HM. Effect of phytase and 1, 25-dihydroxycholecalciferol on phytate utilization and quantitative requirement for calcium and phosphorus in young broiler chickens. Poultry Science, $75: 95-110.1996$.

Nelson TS, Shiet TR, Wodzinsld RJ and Ware JH. Effect of supplemental phytase on the utilization of phytate phosphorus by chicks. Journal of Nutrition, $101: 1289-1293.1971$.

Oberleas D. Phytate in : toxicant occurring naturally in foods, 2nd ed., pp. 363-371, National Academy of Science, Washington, D.C. 1973.

Perney KM. Cantor AH, Straw ML and Herkelman KL. The effect on dietary phytase on growth performance and phosphorus utilization of broiler chicks. Poultry Science, 72 : 2106-2114. 1993.

SAS Institute. SAS ${ }^{\mathrm{R}}$ User's guide. Statistics. Version 5th Ed. SAS Institute Inc., Cary, NC. 1990.

Schörner FJ, Hoppe PP and Schwarz G. Effects of microbial phytase and inorganic phosphate in broiler chickens : performance and mineral retention at various calcium levels. Journal of Animal Physiology and Animal Nutrition, $69: 235-244.1993$.

Sebastian S, Touchburn SP, Chavez ER and Lague PC. The effects of supplemental microbial phytase on the performance and utilization of dietary calcium, phosphorus, copper and zinc in broiler chickens fed corn-soybean diets. Poultry Science, 75 : 729-736. 1996. 
Takemasa M, Murakami H and Yamazaki M. Reduction of phosphorus of chicken by addition of yeast phytase. Japanese Poultry Science, 32 : 1-8. 1995.

Vohra P, Gray GA and Kratzer FH. Phytic acid-metal complexes. Proceedings of the Society for Experimental Biology and Medicine, $120: 447-449.1965$.

Yi Z, Kornegay ET, Ravindran V and Denbow DM. Improving phytate phosphorus availability in corn and soybean meal for broiler using microbial phytase and calculation of phosphorus equivalency values for phytase. Poultry Science, $75: 240-249.1996$.

Yi Z, Kornegay ET and Denbow DM. Supplemental microbial phytase improves zinc utilization in broiler. Poultry Science, 75 : 540-546. 1996.

Yonemochi C, Takagi H, Hanazumi M, Hijikuro S, Koide K, Ina T and Okada T. Improvement of phosphorus availability by microbial phytase. Japanese Poultry Science, $37: 154-161$. 2000.

Yoshida M. Design of Experiments for Animal Husbandry, Yokendo, Tokyo. 1983. 